\title{
SURINAME IN DE COLLECTIE-SIX
}

De heer Joh. F. Snelleman schrijft ons:

Velen weten niet, dat reeds in 1613 een Amsterdamsch handeishuis een factorij te Paramaribo bezat. Maar de Engelschen zijn de eersten geweest die in Suriname een kolonie vestigden; zij hebben 't korten tijd verlaten en toen zijn de Franschen gekomen, na hen weder de Engelschen, door Willoughby uitgezonden, die het land the sweetest place noemde that ever was seen. Dat was in 1650; zeventien jaar later kwam Krijnssen met zijn Zeeuwsche vloot en de Engelschen konden toen heengaan; maar in hetzelfde jaar dat het bezit van Suriname bij den vrede van Breda aan de Hollanders was gewaarborgd, voer een Engelsche vloot de Suriname op, beschoot het fort en plunderde de kolonie; dat was in 1667; plantages werden verwoest, suikermolens in brand gestoken, blanken, slaven en goederen weggevoerd; oorlogvoeren was destijds een rude métier. Het volgend jaar nam Krijnssen de kolonie terug, en sinds dien tijd is Suriname, met twee korte onderbrekingen, een Nederlandsche kolonie gebleven.

Wie kon nu rechten op het veroverde gebied doen gelden? De Zeven Provinciën of Zeeland alleen ? Jarenlang was daarover geharrewar. En eindelijk, in 1682, liet Zeeland zich vinden tot een overdracht aan de W.-I. Compagnie, die de kosten der Zeeuwsche expeditie, ten bedrage van $f 260.000$, aan Zeeland zou vergoeden, „zou" indien zij had gekund; maar er was geen geld, er was gejammer over den desolaten toestand. Redding kon er komen, meende men, door de kolonie te stellen onder het beheer eener Societeit van Suriname, waarvan firmanten waren de W. I. C., de stad Amsterdam en Corn. van Aerssen van Sommelsdijk, ieder voor een derde deelnemend in de lusten en lasten der nieuwe maatschappij.

Ik heb dit stukje geschiedenis noodig omdat naast mij ligt een stapeltje boeken over Suriname, oude en zeer oude, meerendeels zeldzame, enkele aller-zeldzaamst, nooit gezien door oogen die meenden alles te hebben gezien wat over de Wilde Kust is geschreven. Over de kostbaarheid van het stapeltje spreek ik niet; daarvan zal blijken wanneer binnenkort het eerste gedeelte van 
de bibliotheek van jhr. Six van Vromade onder den hamer komt.

Al dadelijk hebben we hier het „Accoord tussen de Gemachtigde van de Ed. Mog. Heeren Staaten van Zeeland, ten eenre; en de Gecommitteerde Bewindhebberen van de Generaale Geoctroyeerde West-Indische Compagnie ter andere zijde; wegens 't Overnemen van de Colonie van Suriname, en wel de kolonie met al haar ap- en dependentiën, geschut, ammunitie, vaartuigen, plantages van vivres, samen voor $f 260.000$. Een afzonderlijke lijst vermeldt de stukken geschut, het buspolver, de ponden lont, de kogels, houwers en portepeen, de snaphaanen en carbyns. Het accoord is niet tot stand gekomen en verderop in hetzelfde boek lezen we de "Conditien, onder de welcke de West-Indische Compagnie, de Stad van Amsterdam ende den Heer van Sommelsdyck in den eygendom etc. van de Colonie van Suriname heeft geadmitteert en aangenomen." De 6de conditie behelst dat genoemde heer „voor gouverneur" naar Suriname zal gaan, en wel uit liefde zonder eenige vergoeding, , des dat ten laste van de Societeyt aan syn Ed. Jaarlycks zal werden toegesonden sodanige quantiteyt Rynse en Franse Wijnen, mitsgaders Speceryen, als de Societeyt honestement oordelen sal te behoren." En vervolgens krijgen we Acte van subsidie van de Provintie van Gelderland, van een man per Compagnie te voet, op den Ordinaris Staat van Oorlog tot maintien van de Colonie van Suriname; zoomede de Acte ut supra van Holland en W. Vriesland, van Zeeland en van Utrecht, het geheele land door.

Minder deftig is de „Korte en wonderlycke beschrijving van de seltsame wanschepsels van menschen, die ghevonden worden in het Coninckrijck Guianae, aen het Meyr Parime. Alsmede van de Satyrs, en van de Vrouwen die Amazoonen genoemt worden"; een jaartal heeft dit boekje van 16 bladzijden niet, maar het moet omstreeks 1660 zijn uitgegeven. Van deze wanschepsels zijn er afgebeeld, menschen zonder hoofd en hals, de oogen in de borst; de prentjes zijn curieus, ook die van de amazonen in hetzelfde koninkrijk „van welcke bewoonderen de voornaemste meest op kleyne Eylantjes en dicke Boomen die in 't water staen sijn woonende, yder moet met een kleyn Schuytje of Vaer-tuygh tot sijn geburen varen", en dat alles, het water, de boomen, de huisjes, de schuitjes en de menschen is nauwkeurig in print verbeeld. Zooals de titel zegt, zijn er wonderbaarlijke wezens gevonden aan het meyr Parime, ook, zooals in den tekst staat „omtrent het Meyr Cattipa”. Van dat meer hooren we nu naders. 
En wel in een boekje van iets lateren datum. Het meer van $\mathrm{Pa}$ rima heeft lang bestaan in de verbeelding van velen; in de nabijheid lag een der beide Dorado's (het andere in Columbia). De hoofdstad heette Manoa del Dorado en daar waren de daken van goud. De onderzoekingen van Schomburgk hebben het meer van de kaarten doen verdwijnen; maar hier is de „Pertinente Beschrijvinge van Guiana gelegen aan de vaste kust van America, waer in kostelijck verhaelt wordt het aenmerckelijckste dat in en omtrent het Landt van Guiana valt". ... . de lange titel wordt gestuit door een aardig vignet van de kust; in 1676 is het boekje te Amsterdam uitgegeven. Wanneer er niet een gebergte lag tusschen de kust en het meer, dan zou men gaan meenen, dat de rivieren Marawijnij, Sorrenamme en Curetijnij in het meer hun oorsprong hebben; aan den n.w. hoek ligt Dorado.... het kaartje met zijn wonderlijke dieren is een en al fantasie; maar vijf jaar vroeger was al verschenen de „Caerte of vertooninge van de Rivieren van Suriname en Commewijne" enz., vermoedelijk de oudste kaart van Suriname die op behoorlijke opneming berust (Rijks-archief en verzameling Jhr. Six). Men vindt erop de namen der plantages en van de eigenaars. De tekst van het boekje is veel beter en de op het titelblad niet genoemde schrijver S. de Beaumont ${ }^{1}$ ) vertelt velerlei voor dien tijd belangrijks over land en volk; en van de manier waarop men ginds groote winst kan behalen met een klein kapitaal.

Van de voordeelen en rijkdommen die men daar kan erlangen vertelt de eveneens niet op het titelblad genoemde auteur $\mathrm{O}$. Keye van het boekje „Beschrijvinge van het heerlijcke ende gezegende Landt Guajana, waar inne gelegen is de seer voorname Lantstreke genaemt Serrenamme", een schat van een boekje, ook naar het uiterlijk, met een voorbericht van taai-taai, ten betooge, dat de mensch altijd weer verlangt naar de plek waar hij is geboren en opgevoed. Het boekje heeft 31 hoofdstukken en het 24ste behandelt de slaven; menschen tot slaven te gebruiken is volstrekt geen ongeoorloofde zaak: $1^{\circ}$. wordt in het oude testament het gebruik toegelaten, en $2^{\circ}$. wordt het in het nieuwe testament niet verboden; voorts worden deze wezens van beesten menschen en daarna van menschen christenen. Het heele kapittel is een merkwaardige bijdrage tot leering van onkundige menschen nopens de dienstbaarheid der slaven; zij (n.l. de slaven) schijnen alleen tot

') Later is mij gebleken, dat des schrijvers naam wel wordt genoemd, maar niet daar waar men hem gewoonlijk zoekt. 
den arbeid geboren en volbrengen dien met vroolijkheid; daarenboven zijn zij ingenomen met den dagelijkschen kost.

Over slaven en slavernij dacht men destijds anders dan tegenwoordig, 't blijkt voldoende uit hetgeen voorafgaat. Een plakkaat van 24 Nov. 1789 zeide onomwonden dat „de Negerhandel behoorde aangemerkt te worden als onafscheidelijk van den bloey en voorspoed dier coloniën, en van de geheele Commersie." Omtrent de zwarte slaven (er waren in den beginne ook roode: de Indianen) lezen we in het boekje van O. Keye, dat zij „worden langs de Kust van Africa gehandelt bij mangelinge tegens allerley Kramerijen als voor Koperen Arm-ringen, Couralen van diversche soorte en Couleuren, Messen, Bijlen, allerhande diergelijcke Yserwerck; ,den importeur kwam de slaaf te staan van 70 tot 75 gulden en de verkoopprijs was $f 125$ of $f 135$ naar gelang de betaling dadelijk volgde of werd uitgesteld.

Bijzonder merkwaardig is het boekje dat tot titel voert „A voyage in the West Indies containing various observations made during a residence in Barbadoes, and several of the Leeward Islands; with some notices and illustrations relative to the city of Paramaribo in Surinam." De schrijver is J. A. Waller, surgeon R. N. en in 1820 verscheen het boekje. Niet alleen omdat het, hoewel bijna 100 jaar oud, nog niet is opengesneden mag het merkwaardig heeten. Het eerst vallen in het oog de plaatjes: een aardige afbeelding van de Suriname-rivier en Paramaribo, het fort met de Engelsche vlag, een neger die zijn korjaal pagaait, vier negers, die een tentboot roeien. Op een volgende plaat zijn afgebeeld voorwerpen door de Indianen gebruikt, boog met pijlen, knots, parel, fluiten van been, vrouwen-schortje e. a. Een derde plaat stelt voor A chief of the Bosjesmans or Bush negroes on a visit to the Governor of Paramaribo. Arwawkas and Charaibes or Caribbee Indians at Surinam." Hier hebben we dus beide volken op één plaatje, maar noch het negertype, noch het indianentype komt voldoende uit. Drie windmolens op een prentje van Barbados vallen ons dadelijk op; niet een fantasie van den teekenaar, want de schr. vertelt „Their mansions n.l. van de planters, were rendered conspicuous on every height, by the tall cabbage-trees and windmills grouped around them." Den 11 den Juli 1808 ging Waller van boord en hij was.... als volgt zegt hijzelf: „I was surprised to find myself on a pleasant green, such as I have often noticed in some of the retired villages of England, embellished with rows of lofty trees and spacious walks underneath them. I could hardly fancy myself in a spacious city, such as I expected 
to find Paramarabo; and was still more surprised, on crossing the green, to find myself in an extensive street filled with noble buildings, and at the same time presenting the appearance of gardens and the country." De Engelsche gouverneur was toen William Carlyon Hughes; eind September van 1808 is hij afgetreden.

Waller is vol lof over Paramaribo en zijn bewoners; een nauwkeurig waarnemer, zooals uit zijn opmerkingen blijkt. De zeer eenvoudige kleeding van de gekleurde bevolking wekt zijn toorn. „I must refer the cause of this scandalous practice to a depravity of morals, which to a European is scarcely credible"; en hij geeft de schuld aan de „white females” (Engelsche dames!).

Antieke boekjes zijn tòch al aardig, maar indien de inhoud belangrijk is en ons boeit, ook omdat zij vertellen van een land dat nu sedert geruimen tijd ons toebehoort, nadat het een keer of tien is veroverd en heroverd door anderen, dan groeit de bekoring die van hen uitgaat. Dan de bandjes! Wil niet het oog óók wat hebben? De een voelt veel voor perkament, dat de kleur heeft gekregen van oud wedgewood en waarop de gouden lijnen en stempels deftig uitkomen; hier is een boekje in geheel bruin leer, op de beide platten hetzelfde gouden stempel „Bataafsche maatschappij tot nut van 't algemeen" in een ovale zon en daaromheen "Amsterdams eerste departement. Schoolbestuur". Het Nut wist't wel: de inhoud is het mooie bandje waard. J. D. Kunitz, voormalig plantage-directeur; is de schrijver, en hij noemt zijn geschrift „Suriname und seine Bewohner oder Nachrichten über die geographischen" en vele andere - ischen Verhältnisse dieses Landes". Hij woonde er 20 jaar en het boekje is van 1805; hij was er dus in den tijd van Jan Nepveu, die voortdurend de Boschnegers achterna zat, en onder wiens gouverneurschap de eerste Surinaamsche courant, „de wekelijksche Woensdagsche” het licht zag; andere couranten waren er in dien gelukkigen tijd niet, althans geen binnenlandsche. En Kunitz heeft dus ook meegemaakt het moment, dat (Nov. 1802) Suriname door de Engelschen werd „overgenomen". Eerst in 1816 heeft dit gescharrel opgehouden, en is Suriname een Nederlandsche kolonie geworden.

Het aantrekkelijke van dit boekje met den weidschen titel is, dat het veel minder geeft dan 't belooft: dagelijksche dingen van Suriname behandelt de schrijver; ook hij looft het land en de stad, die hij „ganz artig" noemt; het is de eenige stad in den lande „so dass der Blick überall auf nichts als Plantagen stosst". Dat is nu anders. Telkens ontmoet de lezer beschrijvingen die hij nergens anders aantreft, de groen, wit, rood en blauw geverfde tentbooten, 
den watermolen die het graan voor het soldatenbrood maalt en die in de plaats kwam van den afgebroken windmolen (ook dààr en toen reeds!). Dan het aspekt van de stad, de bouw-orde; en over de „Bauart der Einwohner” loopen twee hoofdstukken; deze man verzuimt niets, hij geeft de maten van de steenen muurtjes waarop de houten huizen rusten en weet te vertellen dat de planken van het huis één en een kwart duim over elkaar schieten. Verscheidene huizen noemt en beschrijft hij afzonderlijk, ook „das Enkhäusische Haus”, geheel van baksteen, twee verdiepingen hoog, het eerste in de kolonie met vensters van glas. Hoofdstukken over de bewoners des lands, den godsdienst der negers, de levenswijs der blanken, den regeeringsvorm en de lands-kantoren volgen; uitvoerige over de dieren, met latijnsche namen, van tijger tot mier, over de vruchten en over de inlanders, de Boschnegers, „Rebellenunfug bis auf die neuesten Zeiten”. De plantages, des schrijvers vak, heeft hij tot het laatst bewaard; een alleszins belangrijk slot van het zeldzame werkje.

Een Engelsch boek in drie deelen, met een titel, die een heele bladzijde beslaat: „Notes on the West Indies written during the expedition under command of the late general Sir Ralph Abercromby; including observations on the island of Barbadoes, and the settlements captured by the British troops upon the coast of Guiana; likewise remarks relating to the creoles and slaves of the western colonies and the Indians of South America; with occasional hints regarding the seasoning or yellow fever of hot climates." De schrijver is George Pinckard M. D. en „to catch events as they passed and faithfully to note them" was de taak, die hij zich stelde. Brieven aan een vriend zijn 't oorspronkelijk geweest; de eerste is van 30 Oct. 1795, en in 1806 is het boek verschenen. Over Barbados vertelt Pinckard in het eerste deel, en in het tweede tot den 8sten brief; de 9de vangt aldus aan: „Our destination is no langer a secret! The Captain went yesterday on board the Commodore and received his instructions - when the Dutch colonies upon the coast of Guiana were avowed to be the object of our expedition." De 10de begint met de "capture of the united colony of Essequibo and Demerara", en is geschreven in Stabroek. ... „I could have fancied myself in Holland. The land appeared as one wide flat intersected with dykes and canals, the roads mere banks of mud and clay, thrown from the ditches at their sides and the houses bedaubed and painted in tawdry colors, like Dutch toys, giving the wole a striking resemblance to the mother country." Met ongewone uitvoerigheid is deze peri- 
ode beschreven.... iets verder moeten we gaan, naar 1799 , toen de gouverneurs De Friderici van Suriname en Van Batenburg van Berbice, - beide koloniën waren toen in Britsche handen - een overeenkomst sloten betreffende de grens tusschen beide landen. In 1802, bij den vrede van Amiens, werden Suriname, Berbice, Demarary en Essequebo aan Nederland teruggegeven, maar in September 1803 gingen Berbice, Demerary en Essequebo weer in Engelsch bezit over, thans voorgoed, naar menschelijke berekening. Suriname kwam in 1804 aan Engeland, tot 1816. En nu is er niet veel wijsheid noodig om te begrijpen, dat een boek met brieven die aanvangen in 1795, en dat werd uitgegeven in 1806, voor ons Hollanders een dokument van belang is; niet alléén omdat het verhaal wemelt van Hollandsche namen van tallooze „Mijnheers".... naar Jan Adam Kegge heb ik gezocht, maar die was van een latere generatie.

Nieuwe Rotterdamsche Courant 31 October 1925, Av.blad C.

$\mathrm{Na}$ de veiling. Een veiling is een loterij, ook een boekenveiling. Vroeger was de kans iets te winnen grooter dan tegenwoordig, nu de kans om iets goeds machtig te worden, voor de som die men gewoonlijk een prikje noemt veel geringer is geworden. Indertijd, veertig, vijftig jaar geleden kon men te Leiden op goede aucties brochures en boekjes over West-Indië koopen, niet per stuk maar per pak, voor belachelijk lagen prijs. Destijds was West-Indië meer in tel dan de literatuur over West-Indië; thans heeft de belangstelling zich verplaatst.

$\mathrm{Bij}$ de hier vermelde prijzen is het opgeld buiten rekening gelaten. Ik volg de orde in het artikel dat de N. R. C. gaf.

641 . Accoord met de Staten van Zeeland aangegaan wegens de koop en overnemingen van de Colonie van Suriname. Mitsg. het Octroy van H.H Mogende, Condities tussen de drie respective leden, en andere stukken de Societyt van Suriname concernerende (16 stukken, tot 1749) $f 51$.

647. Korte en wonderlycke beschryvinge van de seltsame wanschepsels van menschen die ghevonden worden in het Coninckryck Guianae. Amst (ca. 1660) $f 70$.

643. (Beaumont, S. de) Pertinente beschryvinge van Guiana gelegen aan de vaste kust van America. Amst. 1676. $f$ 100.

654. (Keye, O.) Beschryvinge van het Heerlijcke ende Gezegende Landt Guajana, Waer inne gelegen is de seer voorname Lant-streke genaemt Serrenamme. 's-Grav. (1660). $f 230$.

655. (Keye, O.) Kurtzer Entwurff von Neu-Niederland und Guajana. Einander entgegen gesetzt. Leipz. 1672 f 210.

De tweede uitgaaf van het boek van Keye 654, dezelfde die bij Van Stockum is geveild, staat in Fred. Muller's "Catalogue of books, maps, plates on America", Amst. 1872, genoteerd voor $f$ 125; de Duitsche vertaling (655) voor $f 55$. Reizen deze boeken naar Amerika, wat zeer waarschijnlijk en even jammer is, dan stijgen zij gedurende den overtocht in waarde en dus in prijs.

664 . Waller, J. A. A. A voyage in the West Indies.... with some notices

a. illustr. relative to the city of Paramaribo. London, $1820 f 15$.

656. Kunitz, J. D. Surinam und seine Bewohner. Erfurt, 1805. $f 16$. 
658. Pinckard, G. Notes on the West Indies, including observations on the island of Barbadoes, London, $1806 f 17$.

Van A. van Berkel was er een boek op de veiling (612) met den volgenden titel: Amerikaansche voyagien, behelz. een Reis na Rio de Berbice, gelegen op het vaste Land van Guiana.... Mitsg. een andere na de Colonie van Suriname, gelegen in het Noorderdeel van het gemelde Landschap Guiana. Amst. 1695; ,, avec front. et 2 planches pliées, grav. p. C. Luyken”, zeide de catalogus. Oorspronkelijk werk is het deel dezer Voyagien dat over Suriname handelt niet; met enkele onbeduidende wijzigingen is het een vertaling van George Warren's in 1667 verschenen An Impartial Description of Surinam of een nadruk van de vertaling daarvan die in 1669 is verschenen onder den titel Een onpartijdige Beschrijvinge van Suriname, Gelegen op het vaste Landt van Guiana in Afrika (Zie dr. H. D. Benjamins, Nog eens Aphra Been, W. I. G. II, 1921, 530 v.). P. A. Tiele, Nederl. Bibliogr. van land- en volkenk. Amst. 1884, teekent bij Van Berkel aan, dat deze het eerst den sidderaal heeft beschreven. Tiele verwijst daarbij naar Von Humboldt, Ansichten der Natur. Heeft Von H. dit gezegd, dan wist hij niet dat Van Berkel plagiaat heeft gepleegd. Warren was met dien sidderaal nummer een, Aphra Been, in 1688, nummer twee. Van Berkel's beschrijving verscheen in 1695 .

Een manuscript van 96 folio bladzijden waarin aardige dingen zijn te vinden over West-Indië is in den catalogus der veiling zich gaan verschuilen onder de „Belles lettres”; aldaar staat onder nummer 300 vermeld: Johan Farret, Gedichten, 1642-49; en de toelichtende nota luidt aldus:

Le ms. est illustré du portrait de l'auteur au crayon et quelques dessins au crayon et à l'encre de Chine par Hugo $v$. Swanevelt. Il contient: Texels Uijttocht naer 't Eylant Curaçao $\mathrm{A}^{\circ} 1635$. - Quelques autres poèmes écrits aux Indes Occidentales. Un de ces poèmes avec la remarque: „Gerijmt in West-Indien, op 't Eylant Curaçao. $\mathrm{A}^{\circ} 1638$. begonnen met lust, met hartseer volendt. $\mathrm{A}^{\circ} 1639$. Van de Duynkerckers genomen. $\mathrm{A}^{\circ} 1639$. In Memorie gehouden. $\mathrm{A}^{\circ} 1641$. Op het Papier uijtgeschut. $\mathrm{A}^{\circ} 1642$. Clacht van de verkoude Jochem. - Epithalames, etc. - Deux poemes autographes par $W . v$. Heemskerck et $C$. $v$. Waarder, dédiés à Farret.

Dit ms. heeft $f 125$ opgebracht. Misschien wil de kooper het tijdelijk afstaan aan de redactie van den W. I. G. om het merkwaardigste eruit in dit tijdschrift op te nemen.

Het eerste gedeelte van de boekerij van Jhr. J. W. Six van Vromade (2726 nummers) is van 16 tot 21 November 1925 verkocht door Van Stockums Antiquariaat (J. B. J. Kerling). 